\title{
UPAYA PENINGKATAN RASA INGIN TAHU DAN PRESTASI BELAJAR DENGAN MENGGUNAKAN MODEL PEMBELAJARAN COOPERATIVE PROBLEM SOLVING YANG DILENGKAPI DENGAN LKS BERBASIS DRILL AND PRACTICE PADA MATERI HIDROKARBON KELAS X-6 SEMESTER GENAP DI SMA NEGERI KEBAKKRAMAT TAHUN AJARAN 2016/2017
}

\author{
Mukti Aulia Ulfah, Endang Susilowati ${ }^{*}$, dan Widiastuti Agustina E. S. \\ Program Studi Pendidikan Kimia, FKIP,Universitas Sebelas Maret, Surakarta, Indonesia \\ *Keperluan korespodensi, telp : 081548553791, email : endwati@yahoo.co.id
}

\begin{abstract}
ABSTRAK
Penelitian ini bertujuan untuk meningkatkan rasa ingin tahu dan prestasi belajar siswa kelas X-6 SMA Negeri Kebakkramat pada materi hidrokarbon dengan menerapkan model pembelajaran Cooperative Problem Solving (CPS) dilengkapi dengan LKS berbasis drill and practice. Penelitian ini merupakan penelitian tindakan kelas yang terdiri dari dua siklus. Subyek penelitian ini adalah siswa kelas X-6 SMA Negeri Kebakkramat tahun ajaran 2016/2017. Data diperoleh melalui wawancara, observasi, tes, dan angket. Teknik analisis data yang digunakan adalah analisis deskriptif. Hasil penelitian menunjukkan bahwa penggunaan model pembelajaran Cooperative Problem Solving (CPS) dilengkapi dengan LKS berbasis drill and practice dapat meningkatkan rasa ingin tahu dan prestasi belajar siswa pada materi hidrokarbon. Peningkatan rasa ingin tahu belajar siswa dapat dilihat dari kenaikan presentase siswa sebesar $80 \%$ pada siklus I dan meningkat menjadi $88,57 \%$ pada siklus II. Prestasi belajar siswa dapat dilihat pada aspek pengetahuan, sikap, dan keterampilan. Berdasarkan hasil tes siklus I ketercapaian aspek pengetahuan pada siklus I sebesar $51,43 \%$ dan meningkat menjadi $77,14 \%$ pada siklus II. Ketercapaian aspek afektif siswa sebesar $82,86 \%$ pada siklus I dan meningkat menjadi $91,43 \%$ pada siklus II.
\end{abstract}

Kata kunci : Cooperative Problem Solving (CPS), LKS berbasis drill and practice, rasa ingin tahu, prestasi belajar, hidrokarbon.

\section{PENDAHULUAN}

Pendidikan merupakan usaha sadar dan sistematis untuk mencapai taraf hidup yang lebih baik. Pendidikan diharapkan mampu meningkatkan sumber daya manusia untuk dapat mendukung tercapainya salah satu tujuan pembangunan nasional yang tercantum dalam pembukaan UUD 1945 yaitu mencerdaskan kehidupan bangsa. Sebagian besar bangsa di dunia menjadikan pendidikan sebagai prioritas utama karena melalui pendidikan, karakter suatu bangsa dapat dibentuk dan dikembangkan. Namun, di Indonesia masih terdapat banyak masalah dalam aspek pendidikan. Salah satu diantara- nya yaitu rendahnya mutu dan kualitas pendidikan di Indonesia. Berbagai upaya telah dilakukan pemerintah untuk meningkatkan mutu dan kualitas pendidikan, salah satunya dengan pembaharuan kurikulum pendidikan [1]

Sampai saat ini, Indonesia telah mengalami beberapa kali perubahan kurikulum mulai dari kurikulum 1994, Kurikulum Berbasis Kompetensi (KBK), Kurikulum Tingkat Satuan Pendidikan (KTSP), dan kurikulum 2013. Saat ini, penerapan KTSP dan kurikulum 2013 bergantung pada kondisi siswa, guru, dan sekolah. Salah satu sekolah yang masih menerapkan KTSP adalah SMAN Kebakkramat. Kegiatan belajar dalam 
KTSP berfokus kepada kegiatan aktif siswa dalam membangun makna atau pemahaman [2].

Berdasarkan pengamatan di kelas X-6 SMA Negeri Kebakkramat pada tanggal 11 Januari 2017, wawancara dengan guru mata pelajaran kimia, dan melihat arsip nilai mata pelajaran kimia siswa kelas $X$ dapat diidentifikasi permasalahan dalam proses pembelajaran. Hasil wawancara dengan guru kimia kelas X SMA Negeri Kebakkramat, menunjukkan bahwa materi hidrokarbon adalah materi yang dianggap sulit bagi siswa. Materi tersebut merupakan salah satu materi penting dalam kimia, karena materi ini merupakan dasar untuk materi lanjutan seperti turunan alkana di kelas XII, sehingga masalah tersebut harus segera diatasi. Hasil wawancara ini kemudian diperkuat dengan hasil ulangan harian siswa bahwa pada nilai hidrokarbon selama dua tahun terakhir, masih banyak siswa yang belum mencapai nilai KKM yang ditetapkan oleh sekolah yaitu 75. Berdasarkan Tabel 1.1 dan Tabel 1.2 dapat diketahui bahwa tingkat ketuntasan siswa pada materi hidrokarbon masih rendah.

Tabel 1.1. Data Ketuntasan Materi Hidrokarbon Tahun Pelajaran 2014/2015

\begin{tabular}{ccc}
\hline Kelas & $\begin{array}{c}\text { Rata-Rata Nilai } \\
\text { Hidrokarbon }\end{array}$ & $\begin{array}{c}\text { Ketuntasan } \\
(\%)\end{array}$ \\
\hline X-1 & 63,50 & 35,71 \\
X-2 & 64,15 & 40,74 \\
X-3 & 63,79 & 46,15 \\
X-4 & 63,68 & 31,03 \\
X-5 & 72,20 & 76,50 \\
\hline
\end{tabular}

Tabel 1.2. Data Ketuntasan Materi Hidrokarbon Tahun Pelajaran 2015/2016

\begin{tabular}{ccc}
\hline Kelas & $\begin{array}{c}\text { Rata-Rata Nilai } \\
\text { Hidrokarbon }\end{array}$ & $\begin{array}{c}\text { Ketuntasan } \\
(\%)\end{array}$ \\
\hline X-1 & 62,80 & 26,70 \\
X-2 & 60,00 & 31,03 \\
X-3 & 59,68 & 31,03 \\
X-4 & 65,29 & 40,74 \\
X-5 & 71,13 & 66,67 \\
\hline
\end{tabular}

Arsip nilai Ulangan Akhir Semester ganjil mata pelajaran kimia siswa SMA Negeri Kebakkramat tahun ajaran 2016/2017 menunjukkan bahwa nilai rata-rata kelas X-6 adalah 58,57 sedangkan ketuntasannya hanya sebesar $31,42 \%$. Data nilai Ulangan Akhir Semester ganjil mata pelajaran kimia rata kelas X-6 SMA Negeri Kebakkramat tahun ajaran 2016/2017 dapat dilihat pada Tabel 1.3.

Tabel 1.3. Hasil Nilai UAS Gasal Kelas X6 Tahun Pelajaran 2016/2017

\begin{tabular}{ccc}
\hline Kelas & Rata-rata Kelas & $\begin{array}{c}\text { Ketuntasan } \\
(\%)\end{array}$ \\
\hline X-1 & 68,61 & 47,22 \\
X-2 & 64,58 & 38,89 \\
X-3 & 66,33 & 44,44 \\
X-4 & 75,61 & 66,67 \\
X-5 & 76,34 & 70,00 \\
X-6 & 58,57 & 31,42 \\
\hline
\end{tabular}

Observasi tentang proses pembelajaran menunjukkan bahwa pelaksanaan pembelajaran masih menggunakan model pembelajaran konvensional, dimana proses pembelajaran yang berlangsung masih berpusat kepada guru (Teacher Center Learning), guru menyampaikan materi dan murid hanya mendengarkan serta mencatat materi. Model pembelajaran tersebut praktis, namun kurang menumbuhkan rasa ingin tahu siswa dalam belajar.

Hasil pengamatan di kelas X-6 menunjukkan bahwa siswa jarang mengajukan pertanyaan, tidak ada siswa yang menjawab pertayaan tanpa ditunjuk, siswa jarang mengemukakan pendapat, kurang inisiatif ketika mengerjakan tugas di depan kelas, dan masih terdapat beberapa siswa yang tidak membawa buku pegangan seperti buku paket atau LKS. Oleh karena respon siswa yang pasif saat proses pembelajaran, maka dapat dilihat bahwa rasa ingin tahu siswa kelas X-6 tergolong rendah. Dalam proses pembelajaran, siswa diharapkan memiliki rasa ingin tahu yang tinggi terhadap pengetahuan agar ilmu yang diperoleh berkembang dan bertambah banyak. Siswa yang memiliki keingintahuan terhadap materi 
akan membuat ilmunya jauh lebih banyak dibandingkan siswa yang hanya diam dan menunggu penjelasan dari guru. Hal tersebut tentu akan berpengaruh terhadap hasil belajar yang diperoleh siswa.

Dari beberapa masalah tersebut dapat diketahui bahwa rendahnya rasa ingin tahu dan prestasi belajar siswa disebabkan oleh model pembelajaran yang di terapkan belum tepat. Oleh karena itu, dibutuhkan perbaikan pada proses pembelajaran yang diharapkan mampu berdampak pada hasil belajar siswa. Sebagai tindak lanjut untuk permasalahan yang terjadi maka perlu dilakukan penelitian tindakan kelas (PTK). Tujuan PTK adalah memperbaiki kualitas proses pembelajaran dengan sasaran akhir memperbaiki hasil belajar siswa, sehingga PTK mempunyai manfaat yang sangat besar dalam meningkatkan kualitas pembelajaran dikelas [3].

Salah satu langkah yang dapat digunakan dalam menyelesaikan permasalahan di kelas X-6 SMA Negeri Kebakkramat adalah dengan menerapkan model pembelajaran Cooperative Problem Solving (CPS). CPS merupakan model pembelajaran dimana siswa bekerjasama dalam kelompok, berbagi ide dan membantu satu sama lain dalam memacahkan masalah yang diberikan oleh guru [4]. Model pembelajaran CPS mendorong siswa untuk mengkontruksi sendiri pengetahuannya melalui diskusi pemecahan masalah. Siswa dilatih untuk menyelesaikan masalahnya secara berkelompok. Dari penerapan model pembelajaran ini, siswa menjadi lebih mudah untuk memahami materi, karena pemecahan masalah dalam kelompok akan meningkatkan pemahaman siswa terhadap materi, sehingga dapat meningkatkan prestasi belajar siswa. Tahapan dalam pelaksanaan CPS yaitu, pengenalan masalah, perencanaan pemecahan masalah, pemecahan masalah, dan evaluasi [5].

Penerapan model pembelajaran CPS meningkatkan prestasi belajar maupun sikap di bandingkan dengan penerapan model konvensional [6]. Penerapan model pembelajaran CPS juga menunjukkan adanya peningkatan dalam proses pembelajaran yang semakin aktif dan efektif dimana banyaknya siswa yang bertanya, mengemukakan pendapat, menulis jawaban soal, dan menjawab pertanyaan tanpa ditunjuk oleh guru [7]. Penerapan model CPS diharapkan mampu memancing dan meningkatkan rasa ingin tahu siswa dalam memecahkan masalah yang dihadapi dalam pembelajaran kimia dan meningkatkan prestasi belajar siswa khusunya pada materi hidrokarbon.

Model pembelajaran yang diterapkan akan berhasil apabila ditunjang dengan media pembelajaran yang baik. Pemakaian media pembelajaran dapat membangkitkan rasa ingin tahu, motivasi dan rangsangan kegiatan belajar [8]. Media ini bertujuan untuk membantu siswa dalam mengembangkan konsep, melatih siswa untuk menemukan dan mengembangkan proses belajar mengajar, sebagai alat bantu guru dan siswa dalam melaksanakan proses belajar mengajar, membantu siswa untuk menambah info tentang konsep, dan membantu siswa memperoleh catatan materi yang dipelajari dalam melakukan kegiatan pembelajaran.

Media yang dapat digunakan untuk membantu siswa belajar mandiri dan bisa meningkatkan kemampuan siswa dalam menganalisis soal adalah LKS yang berbasis drill and practice. Model drill and practice mengharuskan siswa berlatih soal secara terus menerus sehingga siswa mudah memahami materi dengan membahas soal-soal sesuai materi [9]. LKS berbasis drill and practice dapat diterapkan pada mata pelajaran kimia khususnya untuk materi hidrokarbon agar dapat merangsang siswa untuk aktif berpikir, aktif berlatih menyelesaikan soal-soal dan aktif dalam proses pembelajaran. Pada dasarnya dengan lebih banyak berlatih soal, siswa akan banyak bertanya jika menemui kesulitan agar bisa paham. Secara tidak langsung, hal ini akan menumbuhkan rasa ingin tahu siswa dalam belajar. Kombinasi antara model pembelajaran CPS dan LKS berbasis Drill and Practice ini merupakan suatu upaya untuk dapat meningkatkan rasa ingin tahu dan 
prestasi belajar siswa kelas X-6 SMA Negeri Kebakkramat.

\section{METODE PENELITIAN}

Penelitian ini merupakan Penelitian Tindakan Kelas (PTK) yang dilaksanakan dalam dua siklus. Setiap siklusnya terdapat empat tahapan, yaitu perencanaan, pelaksanaan, observasi, dan refleksi [10]. Subjek penelitian adalah siswa kelas X-6 SMA Negeri Kebakkramat tahun ajaran 2016/2017. Pemilihan subjek dalam penelitian ini didasarkan pada hasil observasi yang dilakukan pada saat prasiklus, dimana subjek yang dipilih tersebut teridentifikasi mempunyai permasalahan dalam pembelajaran yaitu rasa ingin tahu dan prestasi belajar yang rendah.

Data yang dikumpulkan meliputi data tentang keadaan siswa yang berupa data kualitatif dan kuantitatif. Data kualitatif diperoleh dari hasil observasi, angket rasa ingin tahu, angket afektif, dan wawancara. Data kuantitatif didapat dari hasil penilaian prestasi belajar siswa pada materi hidrokarbon yang meliputi aspek afektif dan pengetahuan baik pada siklus I maupun siklus II.

Teknik analisis data pada penelitian ini menggunakan analisis deskriptif. Analisis data menggunakan tiga tahap yaitu reduksi data (pengelolaan data), penyajian data (mengorganisasikan data kedalam suatu bentuk tertentu sehingga datanya terlihat lebih utuh), dan triangulasi atau pemeriksaan keabsahan data dengan memanfaatkan sesuatu yang lain diluar data tersebut sebagai pembanding data [10].

\section{HASIL DAN PEMBAHASAN}

Penelitian tindakan kelas ini bertujuan untuk meningkatkan rasa ingin tahu dan prestasi belajar siswa kelas X-6 SMA Negeri Kebakkramat pada materi hidrokarbon dengan menerapkan model pembelajaran CPS dilengkapi LKS berbasis drill and practice. Rasa ingin tahu siswa dalam proses pembelajaran meliputi memancing informasi, mengetahui lebih dalam dan meluas, dan meningkatkan motivasi belajar. Prestasi belajar yang diukur meliputi aspek pengetahuan dan afektif.

Penelitian ini dilakukan dalam 2 siklus yaitu siklus I dan siklus I. Masingmasing siklus terdiri dari tahap perencanaan, tahap pelaksanaan tindakan, tahap pengamatan dan tahap refleksi [10]. Proses pembelajaran menggunakan model CPS dilakukan dalam kelompok untuk memberikan kesempatan kepada siswa untuk jujur, percaya diri, gotong royong dan tanggung jawab dalam kelompoknya.

\section{Siklus I}

\section{a. Perencanaan}

Pada tahap perencanaan siklus I dilakukan penyusunan silabus, RPP, LKS berbasis drill and practice, instrumen penilaian rasa ingin tahu siswa, serta instrumen prestasi belajar. Berdasarkan data silabus diketahui bahwa materi hidrokarbon memiliki alokasi waktu 5 jam pelajaran (5jp). Perincian pembelajaran pada siklus I yaitu 3jp (3 x 45 menit) untuk penyampaian materi dan 2jp ( $2 \times 45$ menit) untuk evaluasi siklus I.

\section{b. Pelaksanaan}

Tahap pelaksanaan siklus I terdiri atas 3 kali pertemuan, dengan 2 kali pertemuan untuk penyampaian materi dan 1 kali pertemuan untuk evaluasi siklus I. Pertemuan 1-2 dilakukan diskusi kelompok. Pembelajaran diawali dengan guru memberikan apersepsi dan menjelaskan tujuan serta model pembelajaran yang akan digunakan, lalu guru menjelaskan materi yang akan dipelajari secara singkat dan memberikan LKS berbasis drill and practice kepada siswa. Kemudian guru miminta siswa berkelompok seperti kelompok yang telah ditentukan di awal. Siswa di minta mengerjakan soal yang ada dalam LKS dan didiskusikan dengan kelompoknya. Guru berkeliling untuk memeriksa pemahaman siswa. Setelah selesai diskusi siswa diminta untuk mempresentasikan hasil diskusinya. Setelah itu guru membimbing siswa menyimpulkan dari pembelajaran. Pada pertemuan terakhir atau pertemuan kelima, 
dilaksanakan evaluasi siklus I yang meliputi penilaian aspek pengetahuan dimana siswa harus menjawab soal ulangan dan waktu yang tersisa digunakan untuk mengisi angket penilaian diri.

\section{c. Pengamatan}

Hasil penilaian observasi dan analisis hasil tes pada siklus I dapat dibuat dalam beberapa kategori-kategori. Hasil penilaian rasa ingin tahu siswa dapat dibuat kategori seperti pada Gambar 1.

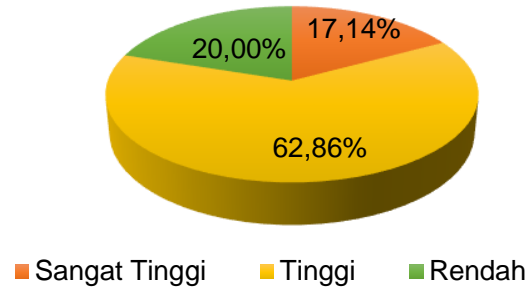

Gambar 1. Ketercapaian Aspek Rasa Ingin Tahu Siswa Siklus I

Gambar 1 menunjukkan bahwa secara umum capaian aspek rasa ingin tahu siswa sudah cukup tinggi. Hal itu ditunjukan dari jumlah siswa sangat tinggi dan tinggi melampaui target siklus I sebesar $75 \%$. Semua indikator pada aspek rasa ingin tahu belajar terpenuhi.

Hasil penilaian aspek pengetahuan bisa dilihat pada Gambar 2.

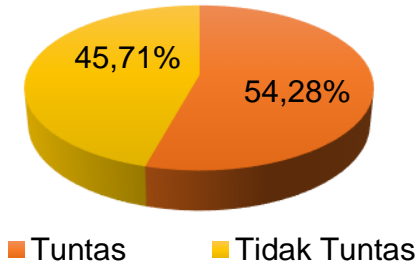

Gambar 2. Ketercapaian Aspek Pengetahuan Siswa Siklus I

Gambar 2 menunjukkan bahwa siswa yang nilai yang tuntas masih di bawah target siklus I yaitu $70 \%$. Hasil siklus I terdapat satu indikator yang belum tuntas yaitu menentukan isomer struktur senyawa alkana, alkena, dan alkuna, sehingga perlu dilanjutkan ke siklus II.

Hasil angket dan observasi afektif dapat dilihat pada Gambar 3 berikut ini.

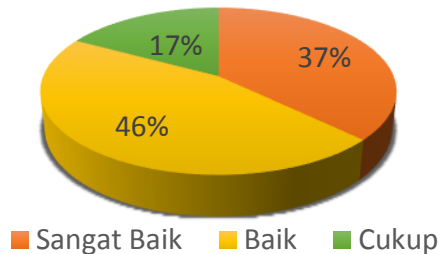

Gambar 3. Ketercapaian Aspek Afektif Siswa Siklus I

Gambar 3 menunjukkan jika secara umum capaian aspek afektif siswa sudah baik hal itu ditunjukan dari jumlah siswa kategori sangat baik dan baik yang sudah mencapai target siklus I sebesar $75 \%$.

\section{d. Refleksi}

Hasil penilaian siklus I yang dilakukan menunjukkan masih terdapat aspek yang belum mencapai target yaitu aspek pengetahuan. Sehinga perlu dilakukan perbaikan agar aspek pengetahuan mencapai target. Meskipun aspek rasa ingin tahu siswa dan afektif telah mencapai target, tetapi perlu ditingkatkan lagi. Oleh karena itu, perlu dilaksanakan siklus II yang diharapkan dapat mencapai target yang sudah ditentukan.

\section{Siklus II}

\section{a. Perencanaan}

Pada pelaksanaan siklus II ini lebih difokuskan untuk perbaikan terhadap kendala-kendala yang muncul pada siklus I. Materi yang diberikan juga fokus pada indikator-indikator yang belum mencapai ketuntasan yaitu menentukan isomer struktur senyawa alkana, alkena, dan alkuna. Pemberian evaluasi juga terbatas pada soal dengan indikatorindikator yang belum tuntas saja. Kelompok diskusi pada siklus II ini dibagi berdasarkan nilai yang telah didapat siswa pada evaluasi siklus I. Hal ini dilakukan agar siswa yang sudah tuntas di siklus I dapat membantu temannya yang belum tuntas dalam satu kelompok tersebut bisa tuntas dalam evaluasi siklus II.

\section{b. Pelaksanaan}

Siklus II ini dilaksanakan dalam 2 kali pertemuan, yaitu 1 kali pertemuan 
untuk penyampaian materi dan 1 kali pertemuan untuk evaluasi siklus II.

Pada pertemuan pertama, guru menjelaskan kepada siswa bahwa pembelajaran ini lebih difokuskan kepada materi yang belum dipahami pada siklus I yaitu menentukan isomer struktur senyawa alkana, alkena, dan alkuna. Guru memberikan soal diskusi agar siswa lebih memahami materi yang diajarkan, setelah itu kelompok yang sudah selesai diminta maju untuk mengerjakan soal di depan dengan kelompok lain bisa bertanya terkait hal yang belum dimengerti. Guru dan siswa bersama membuat kesimpulan di akhir pembelajaran.

Pada pertemuan kedua atau pertemuan terakhir dilaksanakan evaluasi siklus II yang terdiri atas tes aspek pengetahuan berupa 15 soal objektif dan sisa waktunya digunakan untuk mengisi angket penilaian diri.

\section{c. Pengamatan}

Hasil observasi dan analisis tes yang sudah dilakukan pada siklus II dapat dilihat dari hasil pada masingmasing aspek, yaitu aspek aktivitas belajar, pengetahuan, dan sikap. Hasil observasi dan analisis angket aspek rasa ingin tahu siswa siklus II dapat dilihat pada Gambar 4.

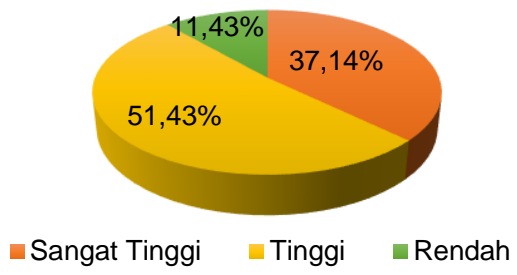

Gambar 4. Ketercapaian Aspek Rasa Ingin Tahu Belajar Siswa Siklus II

Hasil yang disajikan pada Gambar 4 menunjukkan capaian siswa yang berkategori sangat tinggi dan tinggi sudah melampaui target yang direncanakan dan semua indikator juga sudah mencapai target sebesar $75 \%$, sehingga, penilaian aspek rasa ingin tahu siswa dilakukan sampai siklus II ini.

Hasil tes aspek pengetahuan siklus II dapat dilihat pada Gambar 5 .

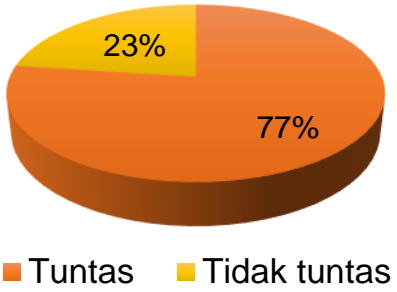

Gambar 5. Ketercapaian Aspek Pengetahuan Siswa Siklus II

Jumlah capaian aspek pengetahuan siklus ini sebesar $77,14 \%$, hasil ini sudah melampaui target sebesar $70 \%$. Semua indikator pada siklus ini juga sudah mencapai target yang sudah direncanakan sehingga penilaian aspek pengetahuan siswa diakhiri pada siklus II.

Hasil observasi dan analisis aspek afektif siswa siklus II dapat dilihat pada Gambar 6.

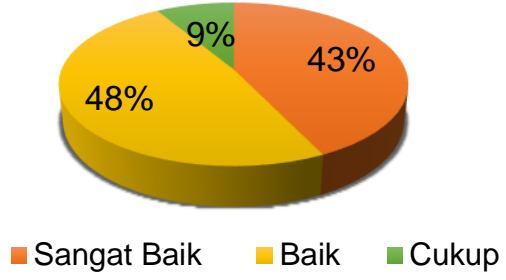

Gambar 6. Ketercapaian Aspek Afektif Siswa Siklus II

Hasil yang disajikan pada Gambar 6 menunjukkan capaian siswa yang berkategori sangat baik dan baik sudah melampaui target yang direncanakan dan semua indikator juga sudah mencapai target sebesar $75 \%$, sehingga, penilaian aspek sikap dilakukan sampai siklus II ini.

\section{d. Refleksi}

Berdasarkan data yang diperoleh pada siklus II, terlihat semua aspek meliputi aspek rasa ingin tahu siswa, pengetahuan, dan afektif mengalami peningkatan capaian dan sudah melampaui target sehingga penelitian di akhiri pada siklus II.

\section{Perbandingan Hasil 2 Siklus}

Berdasarkan hasil observasi, angket, tes dan wawancara yang telah dilakukan selama proses pembelajaran 
dengan model CPS yang dilengkapi LKS berbasis drill and practice diperoleh data bahwa model tersebut dapat meningkatkan rasa ingin tahu siswa dan prestasi belajar pada materi hidrokarbon. Rasa ingin tahu siswa dinilai dari angket rasa ingin tahu yang diberikan pada akhir siklus. Observasi dan wawancara dilakukan sebagai pembanding untuk mengecek keabsahan data yang diperoleh. Data ketercapaian aspek rasa ingin tahu siswa siklus I dan 2 disajikan pada Gambar 7.

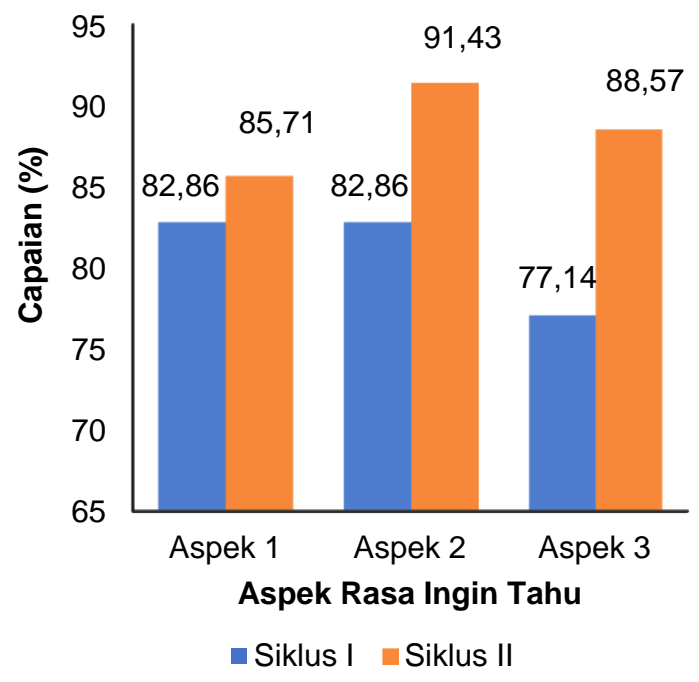

Gambar 7. Diagram Perbandingan Kategori Aspek Rasa Ingin Tahu Siklus I dan Siklus II

Berdasarkan Gambar 7, dapat dilihat bahwa rasa ingin tahu siswa mengalami peningkatan dari siklus I ke siklus II. Hal ini disebabkan oleh penerapan model CPS membuat siswa mempunyai kesempatan yang lebih banyak untuk bertanya maupun mengungkapkan pendapatnya. Semakin sering bertanya maka siswa akan semakin banyak memperoleh informasi baru yang belum diketahui sebelumnya.

Variabel berikutnya dalam penelitian ini yaitu prestasi belajar yang meliputi aspek pengetahuan dan afektif. Aspek Pengetahuan memiliki target sebesar $70 \%$ siswa tuntas. Pada siklus I terdapat 2 indikator yang harus dicapai, akan tetapi hasil dari siklus I menunjukkan bahwa masih ada 1 indikator yang belum tercapai dan ketuntasan siswa hanya mencapai $51,43 \%$. Presentase ketuntasan aspek pengetahuan siklus I dan siklus II ditunjukkan pada Gambar 8.

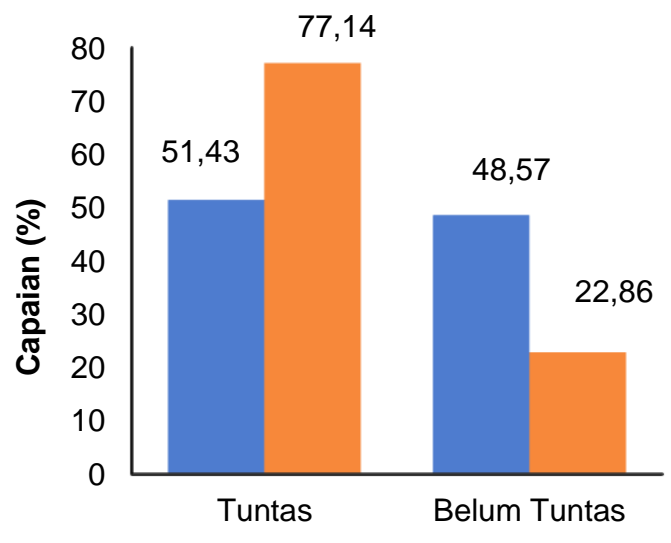

Kategori Aspek Pengetahuan

Siklus $1 \quad$ Siklus 2

Gambar 8. Diagram Ketuntasan Aspek Pengetahuan Siklus I dan Siklus II

Pada siklus I diperoleh ketuntasan aspek pengetahuan sebesar $51,43 \%$ atau sebanyak 18 siswa tuntas. Hasil ini belum mencapai target yang ditentukan namun sudah mengalami peningkatan jika dibandingkan dengan tahun sebelumnya. Belum tuntasnya target pada siklus I ini dapat disebabkan karena siswa belum terbiasa dengan penggunaan model pembelajaran CPS, oleh karena itu pembelajaran dilanjutkan ke siklus II untuk meningkatkan hasil aspek pengetahuan.

Hasil tes siklus II menunjukkan $77,14 \%$ atau sebanyak 27 siswa telah mencapai kriteria ketuntasan minimum sebesar $70 \%$. Hal ini berarti hasil aspek pengetahuan pada siklus II telah mencapai target. Kenaikan aspek pengetahuan dari siklus I dan siklus II dapat disebabkan oleh beberapa faktor, salah satunya yaitu perubahan kelompok yang terjadi pada siklus II. Siswa yang memiliki rasa ingin tahu tinggi dan nilai aspek pengetahuan yang tinggi pada siklus I disebar merata ke dalam 5 kelompok. Diskusi dalam kelompok kecil memberikan kesempatan berpartisipasi yang lebih besar bagi setiap anggota sehingga setiap siswa merasa terlibat dan puas serta mencegah dominasi anggota tertentu dalam proses pembelajaran.

Aspek sikap memiliki target sebesar $75 \%$ siswa tuntas. Kategori 
ketuntasan sikap terdiri dari sikap sangat baik dan sikap baik. Berikut dapat dilihat perbandingan kategori aspek afektif pada Gambar 9.

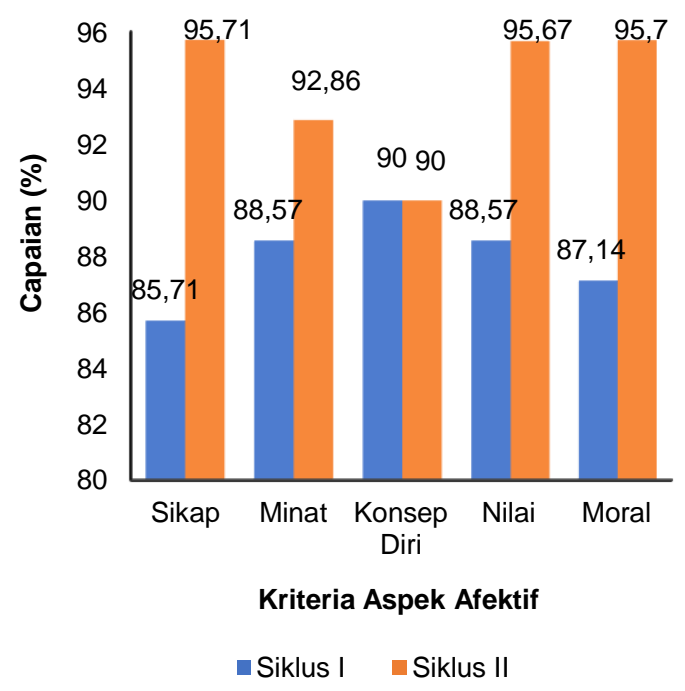

Gambar 9. Diagram Perbandingan Kategori Aspek Afektif Siklus I dan Siklus II

Pada siklus I pencapaian aspek afektif sebesar $82,86 \%$. Hasil ini sudah memenuhi target yang telah ditentukan, namun pada pelaksanaan siklus II tetap dilakukan penilaian aspek afektif. Hal ini dilakukan dengan tujuan untuk mengetahui apakah aspek afektif siswa mengalami peningkatan setelah adanya perbaikan pada proses pembelajaran. Hasil data yang diperoleh pada siklus II mengalami peningkatan menjadi $91,43 \%$.

Hasil penilaian yang diperoleh pada siklus II dapat dinyatakan bahwa penelitian tindakan kelas ini berhasil karena semua aspek yang diukur telah mencapai target yang ditentukan. Dalam penelitian tindakan kelas, penelitian dapat dinyatakan berhasil apabila masing-masing indikator yang diukur telah mencapai target yang telah ditetapkan. Penelitian ini dapat disimpulkan berhasil karena masing-masing indikator proses dan prestasi belajar meliputi rasa ingin tahu siswa, pengetahuan dan afektif yang diukur telah mencapai target dan mengalami peningkatan.

Dari hasil tindakan, pengamatan dan pembahasan dapat ditarik kesim- pulan bahwa penerapan model pembelajaran Cooperative Problem Solving (CPS) dilengkapi dengan LKS berbasis drill and practice dapat meningkatkan rasa ingin tahu dan prestasi belajar siswa kelas X-6 pada materi hidrokarbon di SMA Negeri Kebakkramat tahun ajaran 2016/2017.

\section{KESIMPULAN}

Berdasarkan hasil penelitian yang telah dilakukan, maka dapat disimpulkan bahwa penerapan model pembelajaran Cooperative Problem Solving yang dilengkapi dengan LKS berbasis drill and practice dapat meningkatkan rasa ingin tahu dan prestasi belajar siswa pada materi Hidrokarbon kelas X-6 SMA Negeri Kebakkramat tahun ajaran 2016/2017. Peningkatan rasa ingin tahu siswa dapat dilihat dari kenaikan presentase siswa sebesar $80 \%$ pada siklus I dan meningkat menjadi $88,57 \%$ pada siklus II. Peningkatan prestasi belajar siswa meliputi aspek pengetahuan pada siklus I sebesar $51,43 \%$ dan meningkat menjadi $77,14 \%$ pada siklus II. Ketercapaian aspek afektif siswa sebesar $82,86 \%$ pada siklus I dan meningkat menjadi $91,43 \%$ pada siklus II.

\section{UCAPAN TERIMA KASIH}

Penelitian ini dapat terselenggara dengan baik karena bantuan dari berbagai pihak. Oleh karena itu penulis ingin mengucapkan terima kasih kepada Kepala SMA Negeri Kebakkramat, Bapak Drs. Bambang S. Maladi, M.Pd atas izin yang diberikan kepada penulis untuk melakukan penelitian, dan kepada guru kimia kelas X Ibu Ida Lastari, S.T yang telah memberikan bantuan dan arahan selama penelitian, serta kepada siswa-siswi kelas X-6 SMA Negeri Kebakkramat tahun ajaran 2016/2017 yang telah membantu penulis dalam menyelesaikan penelitian ini.

\section{DAFTAR RUJUKAN}

[1] Mulyasa, E. (2014). Pengembangan dan Implementasi Kurikulum 2013. Bandung : PT. Remaja Rosdakarya. 
[2] Muslich, M. KTSP (Kurikulum Tingkat Satuan Pendidikan). Jakarta : PT. Bumi Aksara.

[3] Daryanto. (2011). Penelitian Tindakan Kelas dan Penelitian Tindakan Sekolah. Yogyakarta : Gava Media.

[4] Slavin, R. E., (1997). Educational Psychology: Theory and Practice (5th Ed). Boston : Allyu and Bacon Company.

[5] Heller, K \& P. Heller. (2010). Cooperative Problem Solving in Physics A User's Manual. [Online]. Tersedia:

http://www.aapt.org/Conferences/ne wfaculty /upload/Coop-ProblemSolving-Guide.pdf.
[6] Esan, Femi. (2015). International Journal for Infonomics (IJI), 8(1), 986-989.

[7] Prasetyoningrum, R., Sukardjo, dan Nurhayati, N. D. (2014). Jurnal Pendidikan Kimia (JPK), 3(3), 105110.

[8] Hamalik, O. (2005). Proses Belajar Mengajar. Jakarta: Bumi Aksara.

[9] Arif, Ristian dan Hadi, Syamsu. (2015). Economic Education Analysis Journal, 4(2), 536-548.

[10] Arikunto, S. (2012). Penelitian Tindakan Kelas. Jakarta: Bumi 